This is the author's final, peer-reviewed manuscript as accepted for publication. The publisher-formatted version may be available through the publisher's web site or your institution's library.

\title{
Secular-Islamist cleavage, values, and support for democracy and shari'a in the Arab world
}

Sabri Ciftci

\section{How to cite this manuscript}

If you make reference to this version of the manuscript, use the following information:

Ciftci, S. (2013). Secular-Islamist cleavage, values, and support for democracy and shari'a in the Arab world. Retrieved from http://krex.ksu.edu

\section{Published Version Information}

Citation: Ciftci, S. (2013). Secular-Islamist cleavage, values, and support for democracy and shari'a in the Arab world. Political Research Quarterly, 66(4), 781-793.

Copyright: @ 2012 University of Utah

Digital Object Identifier (DOI): doi:10.1177/1065912912470759

Publisher's Link: http://prq.sagepub.com/content/66/4/781

This item was retrieved from the K-State Research Exchange (K-REx), the institutional repository of Kansas State University. K-REx is available at http://krex.ksu.edu 
Secular-Islamist Cleavage, Values, and Support for Democracy and Shari'a in the Arab World

\author{
Sabri Ciftci \\ Assistant Professor \\ Department of Political Science \\ Kansas State University \\ 222 Waters Hall, Manhattan KS 66506 \\ Phone: 7855323514 \\ Fax: 7855322339 \\ Email: ciftci@ksu.edu
}




\begin{abstract}
Public opinion polls demonstrate that Arab citizens support both democracy and shari’a. I argue that individual values related to the secular-Islamist cleavage are instrumental in explaining this joint support. The analysis of the Arab Barometer survey shows that individuals holding Islamic values are more favorable of shari'a whereas those with secularist values tend to support democracy. However, the bivariate probit estimations also confirm that Arab opinion about these governing principles is more complementary and less divergent. The results imply that constitutional models combining Islam and democracy, rather than strictly secular institutions, may be more acceptable to Arab citizens.
\end{abstract}

Keywords: Shari’a, Democracy, Islam, Secular, Arab Attitudes, Bivariate Probit, Values 
In the aftermath of the Arab awakening, Islamic parties have swept the electoral landscape in parts of the Arab Middle East. While these movements rule out the strict implementation of shari'a, they have nonetheless supported the inclusion of Islamic principles in legislation and social life (Brown, Hamzawy, and Ottoway 2006: 9-10). At the same time, however, Islamic parties of the Arab world have eagerly promoted civil and political liberties in their platforms. Similarly, ordinary citizens appear to be reconciling their attitudes regarding Islamic and democratic forms of governance. Most Muslims have been shown to be highly supportive of both democracy and shari'a (Esposito and Mogahed 2007). The Arab World is no exception as scholars have found that Arab citizens simultaneously hold favorable orientations toward Islamic and democratic forms of government (Jamal 2006; Jamal and Tessler 2008). These empirical facts stand in sharp contrast to the theoretical debate concerning the incompatibility of Islam and democracy (Kedourie 1992; Huntington 1996). This is the starting point of the current study: What explains individual support for democracy and shari’ $a^{1}$ in the Arab World?

A growing research literature finds that factors associated with modernization and social capital explain much of the variation in Muslim support for democracy (Tessler 2002; Bratton 2003; Jamal 2006; Ciftci 2010). Our understanding of the microlevel determinants of support for shari'a, however, is meager. Scholars have yet to understand whether the same or different factors explain favorable views toward democracy and shari'a. In this paper, I argue that values related to the historically rooted secular-Islamist cleavage are likely to inform individual opinion about these governing principles in Arab polities. Two different explanatory logics are employed. First, it is argued that secular-Islamist values generate diametrically opposed effects on support for democracy and shari'a due to a traditional Islamist ideology. Second, the impact of these values is proposed to be congruent on individual support toward both objects thanks to a 
modernist Islamist position. In the paper, I also argue that these rival hypotheses are conditioned by the highly-diverse contextual effects in Arab polities stemming from state-religion relations and the history of democracy. I test the implications of this value-based approach and compare its explanatory power to the alternative explanations of modernization and social capital.

I focus on the Arab world for several reasons. First, this analysis sheds light on the preferences of individuals forming the support base for Islamist parties in these countries. Second, the implementation of shari'a is a crucial component of constitutional theory in the Muslim World where its relevance is recently increasing with the drafting of new constitutions and the amendment of old ones. Hence, investigating the choices of citizens about shari'a and democracy will demonstrate the extent of popular support for constitutional models combining the two governing principles (e.g. democratized shari'a (Feldman 2008). Third, the democracy gap remains a reality in the Arab Gulf countries which have shari'a based political systems. Thus, this analysis may also provide insights about the microlevel foundations of support for shari'a and democracy in these authoritarian settings.

I use survey data from the first wave of the Arab Barometer surveys and run a series of pooled bivariate probit and country level probit estimations for empirical analysis. The results show that Islamist and non-secularist values are highly relevant in explaining the individual orientations toward democracy and shari'a in the Arab World. Arab citizens holding nonsecularist values are less supportive of democracy and more supportive of shari'a. However, the effects of Islamic values on support for these objects are, by and large, complementary. Since the Arab street favors both democracy and shari'a, this may be indicative of popular support toward constitutional models that combine principles of Islamic governance and democracy. 
Attitudes toward Democracy in the Arab World

The literature about the determinants of individual support for democracy in the Muslim World may be helpful in explaining support for shari'a. This literature can be classified in three groups. The first group of studies use modernization theory as a predictor of opinion (Inglehart and Norris 2003; Inglehart and Welzel 2005). They find that the high levels of education and income are significant determinants of Muslim attitudes toward democracy (Jamal 2006; Bratton 2003). In the same vein, a different approach elaborates on the cultural implications of modernization theory and argues that egalitarian gender views predict support for democracy in the Arab countries and throughout the Muslim world (Inglehart and Norris 2003; Ciftci 2010).

A second group of studies utilize the implications of civic culture and social capital theories to explain support for democracy among Muslims. According to these theories, social trust is crucial for the development of democratic values by providing a basis for cooperation among the members of a society (Putnam 1993). While most Arab citizens lack the necessary means for the development of such values, they may be able to find venues for participation and develop an alternative civic culture even within authoritarian settings (Singerman 1996). For example, Jamal (2007a, b) finds that in the Arab Middle East, higher levels of social trust are associated with support for the existing regime; hence, lower levels of trust may be more conducive to democracy.

A third group of studies focus on religiosity to explain support for democracy. An impressive body of literature has concluded that being a devout Muslim is not necessarily incompatible with democratic values and that higher levels of religiosity may not generate negative views of democracy (Tessler 2002; Bratton 2003; Hoffman 2004; Esposito and Mogahed 2007; Hassan 2008; Jamal 2006; Ciftci 2010). 
Notwithstanding its strengths, this research could benefit from two largely neglected venues. First, the existing literature does not examine the impact of Islamic values on support for

democracy. ${ }^{2}$ The crux of the debate about the compatibility of Islam and democracy concerns whether democracy can flourish within an all encompassing worldview of Islam. Therefore, investigating the relation between Islamic values and democracy in the realm of attitudes will contribute to this debate.

Second, previous studies have not discussed support for democracy in relation to support for shari'a. The confrontation between the West and the Islamic world during the colonial period created lively debates about the classical Islamic state, Western forms of government, and the role of shari'a in newly drafted constitutions (Feldman 2008). From the onset of the modernization process in the Muslim world, shari'a and democracy were parts of the same question. Therefore, the analysis of individual attitudes toward democracy will be incomplete without modeling support for shari’a.

\section{Shari'a and the Secular-Islamist Cleavage}

Historical legacies matter and they create path-dependent trajectories that transform culture and values (Inglehart and Welzel 2005). Some scholars argue that the historically-rooted secularIslamist cleavage penetrates into almost all political issues and actions in the Muslim world (Roy 1994; Hunter 1995). The same cleavage may also serve as a potent source of value generation and shape individual attitudes.

The history of shari'a implementation provides insights for understanding the emergence of a secular-Islamist cleavage. During the Middle Ages, Muslims accepted the rule of the despots only to avoid fitna (i.e. anarchy) and as long as shari'a served as a legal principle limiting the 
power of the ruler (Feldman 2008). This balance led to the idealization of a model known as the “medieval compromise” (Filali-Ansary 2003). This model, however, came into question during the Western colonial period. The polarization between the colonial powers and the locals in the Muslim world led to a false impression that Islam is a religion hostile to modern institutions (Ayoob 2007; Filali-Ansary 2003). One dimension of this polarization was most imminently seen in the codification of the Western-style code replacing the shari’a law (Brown 1997; Feldman 2008; Hefner 2011).

Early implementations of modern code did not create fierce opposition as it left the shari'a-based institutions untouched (Brown 1997), but they paved the way for a future clash. What started as an early confrontation between the two civilizations led to the different schools of thought being embedded in the various forms of elitist and popular revivalist movements (Gelner 1981; Karpat 2001). Salafis, modernist intellectuals, and reform-minded positivists were some of the shades one could observe in Muslim lands at the critical juncture of "Islam's meeting with the West” (Ayoob 2007). These intellectual entrepreneurs in the Muslim world came up with unique ways to set apart or reconcile shari’a and democracy.

This historical legacy was also important in the 1970s and 1980s with the increased role of Islam as a social force. During this period, popular support for nationalist and socialist ideologies started to vanish in the Arab world. An anti-secular rhetoric and favorable views toward an Islamic state swept the Muslim ideological landscape (Feldman 2008; Hunter 1998; Zubaida 1993; Anderson 1987; Owen 2004; Ibrahim 1980). The slogan of the period was "Islam is the solution!” It is against this historical background that a secular-Islamist cleavage became a powerful reservoir of individual perceptions about Islamic and Western institutions. 
The rich array of ideological orientations were funneled through the ideological views of a new class of intellectuals such as Mawdudi, Sayyed Qutb, Khomeini, Soroush, El-Fadl, anNaim, and more recently Ramadan, mostly in the form of various responses to modernization, in the latter half of the $20^{\text {th }}$ century (El-Affendi 2003; Ayoob 2007; Hefner 2011). The ideas of Sayyed Qutb, in particular, with the help of the Muslim Brotherhood's organizational strength in Egypt and in the larger Arab world, became an important value generating force in the realm of attitudes. These values became highly relevant in the shaping of individual preferences about various governing principles.

\section{Microlevel Determinants of Support for Shari'a and Democracy}

Given this background, how do values informed by the secular-Islamist cleavage explain attitudes toward shari'a and democracy? One argument might be that, for the Islamists, democracy and shari'a are totally incompatible and, hence, the impact of values on these notions is diametrically opposed. For instance, Mawdudi and Qutb argue that popular sovereignty is at odds with God's rule and that human legislation cannot be a proxy for shari’a (El-Affendi 2003). In fact, Mawdudi "abrogated the independent legislative function of the state, limiting it almost entirely to the interpretation of God's law, shari'a, with the exception of those cases where the Quran and the Sunna [words and deeds of prophet Mohammed] were silent” (Ayoob 2007: 678). It can be argued that individuals following this position may perceive a contradiction between democracy and shari'a. Thus, Islamist values of these individuals may lead to more support for shari'a and less support for democracy. Yet, the same Islamist scholars also introduced some elements of modern constitutional practices like the hybrid theo-democracy model of Mawdudi and Khomeini’s intricate constitutional design combining electoral and religious institutions. 
Thus, even though these traditionalist Islamist scholars assign a higher normative value to shari'a relative to democracy, they do not totally discard the latter as a governing principle. Clearly, there are traces of democratic ideals in their ideological thinking. Thus, Islamist values may also be positively related to support for democracy even from a traditional Islamist position.

Modernist intellectuals, on the other hand, have taken a different approach and searched for the pluralistic roots of Islam to show its compatibility with democracy (El-Fadl et al 2004; El-Affendi 2003; Sachedina 2001). The proponents of this approach argue that shari'a can provide a basis for modern legislation and Muslims can make decisions under the tenets of a democratic system (Ayoob 2007). They assign more weight to the democratic credentials of Islam and search for ways to reconcile shari'a with democracy. For example, the Iranian opposition intellectual Soroush argues that "shari'a is something expandable. You cannot imagine the extent of its flexibility....In Islamic democracy; you can actualize all its potential flexibilities” (Wright 1996: 70). Similarly, European Muslims have also debated the future of Muslim politics in the West and have made attempts to reconcile the popular understanding of shari’a and pluralist institutions (Ramadan 2009: 148).

Beyond these theoretical debates, public opinion polls demonstrate that, by and large, Muslims have reconciled their attitudes toward shari’a and democracy (Esposito and Mogahed 2007; Hassan 2008; Tessler 2011).The results of the “Gallup Poll indicate that wanting Shari’a does not automatically translate into wanting theocracy” (Esposito and Mogahed 2007: 50). More recently, Bayat (2007) argued that the days of traditional Islamist ideology are over and a new generation of educated and religious individuals has taken a post-Islamist turn. He brings evidence from Egypt and Iran to demonstrate how post-Islamists reconcile Islam with democracy 
and work for the implementation of the latter (Bayat 2007). This implies that individuals may not perceive a contradiction between shari’a and democracy.

The secular-Islamist cleavage is characterized by different worldviews about the role of Islam and democracy. As discussed above, the more traditional Islamist view assigns more weight to shari'a while the modernist ideology focuses on the pluralistic features of Islam. Islamist and secular actors utilize this cleavage to mobilize societal actors. As Tessler argues (2011: 1) individual opinion is divided about secular and Islamic governing principles in the Arab world. Thus, in addition to other factors, values about the political, legal and economic aspects of Islam and secularism may explain individual support for shari'a and democracy. Furthermore, since most Arab citizens voice support for both democracy and Islam, Islamic values may shed light on how attitudes about these objects are related. Two hypotheses follow this theoretical argument:

Hypothesis 1: Individuals holding Islamic/non-secular values will be more supportive of shari'a and less supportive of democracy.

Hypothesis 2: Individuals holding Islamic/non-secular values will support both shari’a and democracy.

Sample and Contextual Effects

I use the first Wave of the Arab Barometer Survey, which includes Jordan, Palestine, Algeria, Morocco, Kuwait, Lebanon and Yemen in the analysis (Muslim-only sample). The selected countries provide a diverse sample in terms of political institutions, the constitutional role of shari’a, and trends in public opinion. For example, Algeria, Jordan, Palestine, and Yemen are ranked 'not-free', whereas Kuwait, Morocco, and Lebanon are ranked 'partly free' by the 2010 
surveys of the Freedom House. The Algerian constitution defines Islam as the state religion (Article 3) and Article 9 states that the practices of institutions cannot contradict Islamic morality. The Jordanian constitution states: “neither the state system of monarchy nor the prescriptions related to the religion of Islam may be subject to a constitutional revision” (Article 106). Next to multiple references to Islam as a state religion, shari’a is specified as the constitutional source of legislation in the constitutions of Yemen and Kuwait. The Basic Law of the Palestinian authority carries similar provisions.

The countries in the sample also have different experiences with democracy and Islam. In Jordan, and Palestine, the Muslim Brotherhood is an important actor utilizing the secular-Islamist cleavage. Islam is heavily utilized to provide monarchial legitimacy in Morocco where the king is known as "the commander of the faithful.” In Algeria, the experimentation with democracy ended with a civil war where the fears of an impending Islamic regime led the secularist military to terminate democratic elections. In Yemen and Morocco, the regime has successfully incorporated Islamist actors into a governing coalition. From these divergent examples, it seems reasonable to anticipate that the relationship between Islamic values and democracy/shari'a will be conditioned by these contextual factors. Individuals may have convergent or divergent attitudes toward these two objects depending on the context. I created two variables from the surveys to explore the contextual differences in attitudes toward democracy and shari'a in the Arab world. The first is support for democracy and is constructed using the questions regarding level of agreement with the following statements:

In a democracy, the economy runs badly

Democracies are indecisive and have too much quibbling

Democracies are not good at maintaining order 
Democracy may have its problems but is better than any other form of government

For each item, strongly agree and agree responses are coded as 1 and the categories of disagree/strongly disagree and responses in the form of don't know are assigned a value of 0 to create dichotomous variables. These four variables are then summed and transformed into a binary index measuring support for democracy. ${ }^{3}$ If the sum of these variables is equal to or less than 2 , the dummy variable gets a value of 0 , otherwise it is coded as 1 . This new variable differentiates very strong supporters from weak, ambivalent, and non-supporters of democracy.

The second variable is support for shari' $a$ and is measured with an item asking the respondents to evaluate whether "the government should implement only the laws of the shari'a." Those who strongly agree and agree are assigned a value of 1 and all other responses (including DKs) are given a value of 0 . As such, this variable differentiates weak from ardent supporters of shari'a. This measure is also utilized by the past studies employing support for shari'a in their empirical analysis (Davis and Robinson 2006; Moaddel 2007). Figure 1 tabulates the distribution of responses to these items in each country.

Figure 1 Here

As shown in Figure 1, there is a certain degree of overlap between attitudes toward democracy and shari'a, but in some cases the opinions remain divergent. In most countries, at least $40 \%$ of the respondents support both shari'a and democracy. Not surprisingly, the zeroorder correlation between the two variables is positive (.0031), but not statistically significant. Thus, one can expect that Islamic values will be positively related to both notions. However, in Lebanon most respondents support democracy but not shari'a and the correlation coefficient is negative in Palestine (-.08), Lebanon (-.11), and Kuwait (-.06); whereas, in Algeria, Jordan, and Yemen the opposite pattern prevails.. These divergent preferences may increase the substantive 
effect of Islamic values on shari'a in the latter group of countries and may generate negative effects on support for democracy in the former. In Morocco, 67\% of the respondents support both governing principles. With such a large degree of overlap, it may be difficult to distinguish the impact of values on support for both objects. In cases where Islam is incorporated into the regime (i.e. Morocco and Jordan) attitudes about Islamic values and democracy should be more compatible (correlation coefficients are .06 and .08 respectively). ${ }^{4}$

Model and Variables

I argue that the analysis of individual attitudes toward democracy will be incomplete without modeling the individual determinants of shari'a support in the Arab world. The cross-tabulation of the responses presented in Figure 1 shows a certain degree of overlap between the favorable views toward these notions. Thus, it becomes imperative to control for the dependency between the individual determinants of shari'a and democracy. To that end, the bivariate probit model has been employed. In this technique, probit models are run simultaneously to determine whether they are dependent by assessing the correlation of the error terms. If there is a statistically significant correlation between the error terms of the two equations, the models are dependent. When dependency is observed, it is methodologically more appropriate to run both equations simultaneously. In the pooled model presented below, the significant likelihood ratio test shows that decisions to support shari'a and democracy are dependent, justifying the use of bivariate probit. In specific country models, however, bivariate probit is mostly not justified. Thus, I use probit estimation for country level models. It should be noted that the results are the same in both estimation techniques. 


\section{Independent Variables}

The dependent variables are support for democracy and support for shari'a (introduced above). To measure the effect of secularist values, I used an item asking the respondents to specify their level of agreement about the statement that men of religion should influence the government decisions. This variable measures non-secularist attitudes and it ranges from 1 (strongly disagree) to 5 (strongly agree) where DK responses are the middle category. To test the effect of support for Islamic values, I used two questions capturing the individual orientations about some Islamic principles:

Banks in Muslim countries must be forbidden from charging even modest interest on loans because this is forbidden by Islam.

If a Muslim converts to another religion, he must be punished by execution.

The first item is a measure of Islamic values in economic life and the second question captures a legal dimension related to an Islamic outlook. These variables range from 1 to 5 with the higher end representing stronger attachment to Islamic values (DK responses coded as the middle category). Together, these indicators measure individual values related to the secularIslamist cleavage. I expect these variables to be negatively related to support for democracy and positively to support for shari’a when individuals carry a traditional Islamist opposition and, hence, see a contradiction between democracy and shari'a. However, as discussed above, values may not necessarily lead to divergent orientations toward shari'a and democracy, and Islamic orientations may be compatible with support for both notions.

I also include a variable to test the effect of anti-Western orientations on support toward both objects for a robustness check. I used a question asking the respondents to evaluate whether 
the cultures of the US and other Western countries have positive attributes or not. For the respondents who disagree with this statement, this variable is coded 1 and otherwise 0 .

Level of education and income are used as economic indicators often used in evidence for modernization theory. A variable measuring egalitarian gender attitudes to account for the cultural implications of modernization theory was also used. Variables capturing the different dimensions of trust (interpersonal and political) are used as indicators of civic culture theory. The models also include religiosity, age, and gender as control variables. The effects associated with these variables may take positive or negative signs with respect to support for shari'a and they may not be diametrically opposed to the effects of these indicators on democratic support. Appendix A provides a detailed description of the control variables.

\section{Results}

Table 1 reports the results from the pooled models. Since the list-wise deletion drops a large number of observations, I ran the estimations by including DK responses as middle categories. Both dependent variables range between 1 and 5 with the addition of these responses. However, the dichotomous variable measuring support for democracy includes additional middle category responses, because it is a combination of four items. Since support for shari'a is measured by a single item, it lacks these additional responses and it is constructed by a mid-point split (1-2/3-4). This discrepancy can pose a threat to the validity of the analysis presented below. To account for this difference, in Model 1, I dropped the additional middle category responses in constructing ‘support for democracy’ and estimated the models with dependent variables which are parallel in

construction. ${ }^{5}$ In both models, the LR test of Rho is statistically significant justifying the use of 
bivariate probit. The results of the estimations are very similar in both models with the exception of the variable measuring anti-Western sentiments.

I focus on the results in Model 2 for the purpose of brevity. Overall, the results show that individual values related to the secular-Islamist cleavage are significant predictors of support for both democracy and shari'a. A non-secularist individual is more likely to support shari'a and less likely to support democracy. Similarly, individuals favoring the implementation of the Islamic rules in the legal domain are less likely to support democracy and more likely to support shari’a. However, individuals favoring the installment of Islamic principles in economic affairs are able to reconcile their attitudes toward both governing principles.

Table 1 Here

The economic and cultural implications of modernization theory also have some predictive power. Favorable views of gender equality and higher levels of income generate more support for democracy; whereas, holding egalitarian gender values decreases the likelihood of support for shari'a. Education is a positive determinant in both equations. While the results lend partial support to civic culture theories, religiosity predicts favorable views of shari'a. In accordance with the findings of past studies, being religious does not inform attitudes toward democracy (Jamal 2006; Ciftci 2010).

To demonstrate the substantive impact of each indicator on the joint support for shari'a and democracy, I calculated the marginal effects. These effects, shown in Figure 2, represent the rate of change generated by each covariate for the different combinations of the two dependent variables when all other variables are held constant. I present four sets of statistically significant marginal effects: the likelihood of support for democracy given support for shari'a, the 
likelihood of support for shari'a given support for democracy, the support for shari'a in the lack of support for democracy, and the support for democracy in the lack of support for shari'a. ${ }^{6}$

Figure 2 Here

Given a favorable opinion of shari'a, an individual with non-secularist orientations is less likely to support democracy by $2.4 \%$ (upper-left panel). The same individual is $5.6 \%$ more likely to support shari'a if s/he does not support democracy (bottom-left). It looks like individuals with non-secularist orientations do not favor democracy if they are ardent supporters of shari'a. Interestingly, strong believers in democracy appear to simultaneously support shari’a. For example, all else equal, holding non-secularist orientations increases the likelihood of support for shari’a by $6.1 \%$ given favorable attitudes of democracy (upper-right panel). Finally, some individuals may have a dislike for both objects. A non-secularist individual who holds unfavorable views of shari'a is $3.1 \%$ less likely to support democracy (lower-right panel). A similar pattern is observed for the impact of an individual's legal Islamic outlook but only with modest effects. The ardent supporters of shari'a are less likely to support democracy if they favor Islamic values in the legal sphere. In contrast, strong believers in the democratic order holding similar values are able to reconcile support for both. Combined with the results presented in Table 1, the analysis provides an interesting insight into the microlevel foundations of support for different governing principles in the Arab world. On average, holding non-secularist values and Islamic views of the legal sphere leads to more support for shari'a and less support for democracy. However, individuals are able to bring together their views about both notions if they favor democracy at the same time. In other words, supporters of democracy are more likely to reconcile Islam and democracy even if they hold non-secularist and Islamic values. This finding echoes Bayat's 'post-Islamist turn' argument, according to which the new generation of Islamist 
individuals value notions of democracy and human rights but, at the same time, care about Islamic principles (Bayat 2007).

The results in Figure 2 also show that, in the Arab World, the gender factor may be highly instrumental in explaining support for shari'a and democracy. Firstly, egalitarian gender attitudes, an indicator of cultural modernization theory, consistently affect conditional and exclusive support for shari'a and democracy. An individual who favors gender equality is more likely to support democracy if s/he supports shari'a. Conversely, the same individual is less likely to support shari'a given support for democracy. The opposite effect of gender perceptions can also be observed for exclusive support toward these objects. If individuals carry egalitarian views about gender, they are less likely to support shari'a regardless of their support for democracy, and they are more likely to support democracy regardless of their orientations toward shari'a. Thus, holding positive views of gender equality creates an attitudinal bias favoring democracy with or without support for shari'a. Secondly, a gender gap exists in the realm of attitudes. On average, relative to a man, a woman is $10.1 \%$ less likely to support democracy given her support for shari'a. On the other hand, women are 9.3\% more likely to support shari’a given no support for democracy relative to male respondents.

These results provide average estimates about how individuals holding non-secular and Islamic values reconcile or distinguish their attitudes toward democracy and shari'a in the Arab World. As discussed before, citizens' views may also be conditioned by national factors. To account for this contextual effect, I ran separate probit estimations for each country in the sample. Models with different techniques and specifications were run to check for robustness and, in none of these estimations, did the results change significantly. Including each dependent variable on the right side of the other equation did not prove to be fruitful nor did the 
specification with various interaction terms. Bivariate probit estimation is rarely justified in most models. Thus, I report the results from the probit estimations in Table 2. ${ }^{7}$

Table 2 Here

According to the results in Table 2, a significant level of variation is observed with respect to the determinants of support for democracy and shari'a among citizens of the Arab countries included in the survey. Indicators of Islamic values, particularly non-secularist orientations, are robust predictors of support for these governing principles. An individual with non-secular orientations is more supportive of shari'a and less supportive of democracy in Jordan, Palestine, and Algeria. Referring to Figure 1, these three countries are among the nations with the highest percentage of respondents favoring shari'a but not democracy $(41 \%$, 31\%, and $44 \%$ respectively). This is in line with expectations based on the context with the exception of Yemen. In Yemen, holding non-secular values is inversely related to democracy bringing the attitudes of Yemeni citizens in line with those in the other three countries. Non-secularist orientations appear to be non-relevant in Kuwait, but they are positively related to support for shari'a in Morocco and Lebanon (two cases where overall exclusive support for shari'a is relatively low). Holding Islamic legal views does not lead to divergent opinions in the sample, but these values generate favorable views of shari'a in Palestine, Algeria, and Yemen. Conversely, positive perceptions of legal Islam lead to less support for democracy in Morocco, Kuwait, and Yemen. The impact of individual values on the role of Islam in economic affairs is characterized by a more reconciliatory pattern. While holding Islamic values in the economic realm leads to positive orientations of shari'a in all but two countries (Palestine and Lebanon), it also generates favorable views of democracy in Jordan and Yemen. As expected, the successful incorporation of Islam into the monarchial regimes may account for this distinctive pattern. 
Clement Henry (1990) argues that Islamic banking became more common throughout the Arab World, and its practices are more successful in competitive societies where a synergy exists between Islamist revivalist policies and economic practices. The widespread application and acceptance of Islamic Banking in the Arab World may be informing attitudes in a way that makes the reconciliation of shari’a and democracy possible.

What is to be made of these results? By and large, holding non-secularist and Islamic values leads to more support for shari'a and less support for democracy. However, a closer look at the results also shows that individuals may not always situate their views about shari'a and democracy in divergent directions. Arab citizens holding Islamic values may be more supportive of shari'a, but this does not automatically translates to less support for democracy. Therefore, considering this finding in relation to the distinctive pattern of attitudes about Islamic economics, the country level analysis can also be interpreted in favor of the reconciliation hypotheses (Hypothesis 2).

The results in Table 2 further confirm the contextual relevance of a gender factor. In four of the seven countries (Jordan, Palestine, Algeria, and Morocco), holding egalitarian gender attitudes leads to more support for democracy. This is in support of the cultural implications of modernization theory (Inglehart and Norris 2003; Inglehart and Welzel 2005; Ciftci 2010). The results also show that women are less supportive of democracy in four countries (Jordan, Algeria, Morocco, and Lebanon) and more supportive of shari'a in two (Jordan and Kuwait). Perhaps, the incorporation of Islam into regime in Jordan and Morocco and the history of democracy in Lebanon may account for these patterns of attitudes. Overall, my findings agree with those of the past studies detecting a gender gap in democracy support (Tessler 2002) and the prominence of gender attitudes in Arab public opinion (Inglehart and Norris 2003). Finally, the 
specific country estimations confirm the utility of religiosity for predicting support for shari’a in five of the seven countries.

\section{Discussion and Conclusion}

In this paper, I have examined the underlying dynamics of support for democracy and shari'a. After providing a historical account of the secular-Islamist cleavage, I have extended a valuebased argument to explain the microlevel determinants of these objects. The results show that non-secularist attitudes and the positive perceptions of legal Islamic practices lead to less support for democracy among the ardent supporters of shari'a. At first, this may be indicative of the attitudinal incompatibility between support for Islamic and democratic governing principles. However, supporters of democracy also favor shari'a and are able to find the middle ground between Islamic values and democracy. This is particularly true for the values related to Islamic economics, as individuals favoring the implementation of Islamic banking hold more reconciliatory views of Islam and democracy. Furthermore, the country level analysis shows that while holding non-secularist values leads to divergent views of support for these two governing principles, by and large, Islamic values do not automatically generate opinions in opposite directions. Thus, a fusion of Islam and democracy taking the form of a 'democratized shari'a' (Feldman 2008) or a 'Muslim democracy' (Nasr 2005) may be the norm in the attitudinal realm. The country level analysis demonstrates that, notwithstanding these general patterns, more needs to be explained in order to unfold the subtle contextual differences. Particularly, scholars need to examine the distinct attitudinal patterns about governing principles in countries where Islam is incorporated into the regime through semi-democratic institutions (i.e. Jordan and Morocco). 
In addition to the effects of Islamic and secularist values, one indicator of cultural modernization theory, perceptions of gender equality, powerfully predicts and delineates the citizens' views about democracy and shari'a. The gender dynamic is also relevant to the extent that women are found to be less supportive of democracy and more supportive of shari'a. Past studies argued that the lack of democracy in the Muslim world is related to the status of women (Fish 2002). While no conclusive evidence is provided to determine whether the disadvantaged status of women is due to Islam (which would be a doubtful claim given the revolutionary discourse of Islam about women’s rights (Mernissi 1996)) or due to a patrimonial culture, the results of the analysis show that, in the realm of attitudes, gender and the perception of gender equality powerfully predict support for democracy and shari'a. Whether this can be generalized to the Muslim world or is unique to the Arab Middle East should be investigated in future studies.

As evidenced by the successful Muslim democracies of Turkey and Indonesia, Islamic parties may survive in democratic systems. However, in less secularized Arab systems where political Islamism has significant appeal, the Arab awakening may have opened Pandora's Box. Demands for shari'a may move the balance of the fulcrum toward an Iranian or Saudi model. In the realm of attitudes, there is limited potential supporting a model leaning towards a less democratic Islamic state. Arab citizens are more likely to simultaneously favor shari'a and democracy as governing principles. Thus, democratic models incorporating Islamic values may be more feasible than strict secular democratic arrangements in Arab polities. This is the lesson for the political elite and policymakers designing new constitutions in the Arab world in the aftermath of the awakening. 
Author's Note

An earlier version of this paper was presented at the Annual Meeting of the Middle East Studies Association, December 1-4, 2011, Washington, DC. The author would like to thank to Ethan

Bernick, Michael Wuthrich, the panel participants in MESA Annual meeting, and three anonymous reviewers for their valuable suggestions and feedback. The Arab Barometer surveys are publicly available at http://www.arabbarometer.org/. The replication files and raw data used in this article are available from the author's academic Web site at http://www.k-

state.edu/polsci/faculty/sciftci/research.html. 
${ }^{1}$ Literally, shari'a means "the path to water" or "the path to God" and "shari' a represents the moral compass of a Muslim’s personal and public life.” (Esposito and Mogahed 2007). Hefner describes shari'a as “a system of ethical injunctions as much as 'law' in modern sense.” (Hefner 2011: 2).

${ }^{2}$ Values as predictors of attitudes have been extensively examined by the public opinion scholars in the West (Ingelhart and Welzel 2005; Feldman 2003; Schwartz 1992). In the Muslim and the Arab world, however, the empirical analysis of attitudinal aspects of values is not widely utilized.

${ }^{3}$ The construction of dichotomous variables is related to the model choice which is bivariate probit. An alternative model could be bivarate ordered probit. However, this model requires more restrictive assumptions and, in some of the estimations, it does not converge.

${ }^{4}$ I acknowledge that the contextual effects are certainly more nuanced. In this paper, I make a modest contribution and just show that a contextual variation may be in order.

${ }^{5}$ I thank one of the anonymous reviewers for pointing to this very valid point. I also ran additional models dropping the DK and additional middle category responses in the 'support for democracy’ equation. The results do not change significantly.

${ }^{6}$ When each dependent variable is regressed in the other equation, the model does not converge. I ran additional analysis including only one dependent variable as an exogenous variable in the other equation and adding interactive terms with the measures of Islamic values. The results related to the indicators of Islamic values do not change significantly in these additional models. I prefer not to use these models due to the possible endogeneity problem in these specifications.

${ }^{7}$ The results of these models can be found in author's website. Additional analyses are available upon request. 
Appendix A: Table of the Variables in the Models

\begin{tabular}{|c|c|}
\hline Variables and Statistics & Description \\
\hline Support for Democracy & In a democracy, the economy runs badly \\
\hline Mean:0.55 & Democracies are indecisive and have too much quibbling \\
\hline \multirow[t]{3}{*}{ Std. Dev:0.50 } & Democracies are not good at maintaining order \\
\hline & $\begin{array}{l}\text { Democracy may have its problems but is better than any other form of } \\
\text { government }\end{array}$ \\
\hline & $\begin{array}{l}\text { (5 Category responses of Strongly Agree-Strongly Disagree were coded as } \\
\text { dichotomous measures for each item to create a single variable with values } \\
\text { of } 1 \text { (strong support for democracy) } 0 \text { (no support for democracy). }\end{array}$ \\
\hline Support for Shari’a & The government should implement only the laws of the shari'a \\
\hline Mean:0.74 & (5 Category responses of Strongly Agree-Strongly Disagree were coded as a \\
\hline Std. Dev:0.44 & $\begin{array}{l}\text { dichotomous measure with values of } 1 \text { (strong support for shari’a) } 0 \text { (no } \\
\text { support for shari’a). }\end{array}$ \\
\hline Non-secular Values & Men of religion should influence the government decisions. Values of 1 \\
\hline Mean:3 & (strongly disagree) and 5 (strongly agree). \\
\hline \multicolumn{2}{|l|}{ Std. Dev:1.31 } \\
\hline Islamic View (Economics) & Banks in Muslim countries must be forbidden from charging even modest \\
\hline Mean:4 & interest on loans because this is forbidden by Islam. Values of 1(strongly \\
\hline Std. Dev:1.14 & disagree) to 5 (strongly agree) \\
\hline Islamic View (Legal) & If a Muslim converts to another religion, he must be punished by execution \\
\hline Mean:3.31 & Values of 1 (strongly disagree) to 5 (strongly agree) \\
\hline \multicolumn{2}{|r|}{ 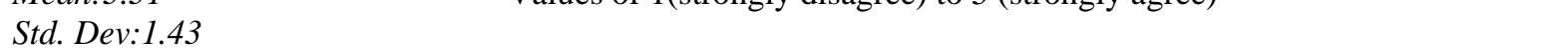 } \\
\hline Political Trust & I'm going to name a number of institutions. For each one, please tell me \\
\hline Mean of five items & how much trust you have in them. Is it a great deal of trust (5), quite a lot of \\
\hline Mean:2.82 & trust (4), not very much trust(2), or none at all (1)? DK are coded as middle \\
\hline \multirow[t]{2}{*}{ Std. Dev:1.10 } & category (3) \\
\hline & Prime minister, the court, parliament, the police, and political parties. \\
\hline Interpersonal Trust & Generally speaking, would you say that most people can be trusted? \\
\hline Mean:.27 & Most people can be trusted (1) You must be very careful in dealing with \\
\hline Std. Dev:.45 & people $(0)$ \\
\hline Perceptions of Gender Attitudes & For each of the statements listed below, please indicate whether you agree \\
\hline $\begin{array}{l}\text { (Mean of three items; the } \\
\text { responses are reordered and }\end{array}$ & (1) strongly, agree (2), disagree (4), or disagree strongly (5), DK (3). \\
\hline higher values represent positive & On the whole, men make better political leaders than women do. \\
\hline orientations) & A university education is more important for a boy than a girl. \\
\hline Mean:3.13 & Men and women should have equal job opportunities and wages \\
\hline \multicolumn{2}{|l|}{ Std. Dev:.9 } \\
\hline Religiosity & How often do you read the Quran? \\
\hline Mean:3.34 & Everyday or almost everyday $\quad$ (5) Several times a week (4) Sometimes \\
\hline Std. Dev: 1.27 & (3) Rarely (2) I don’t read (1) \\
\hline Gender & Female (1) Male (0) \\
\hline \multicolumn{2}{|l|}{ Mean: .5} \\
\hline \multicolumn{2}{|l|}{ Std. Dev: .5 } \\
\hline Income & 10 category level of income \\
\hline \multicolumn{2}{|l|}{ Mean:5.45 } \\
\hline \multicolumn{2}{|l|}{ Std. Dev: 2.87} \\
\hline Education & 7 category education \\
\hline \multicolumn{2}{|l|}{ Mean:3.69 } \\
\hline \multicolumn{2}{|l|}{ Std. Dev: 1.74} \\
\hline Age & 7 category age \\
\hline Mean:2.63 & \\
\hline Std. Dev: 1.40 & \\
\hline
\end{tabular}




\section{References}

Anderson, Lisa. 1987. The State in the Middle East and North Africa. Comparative Politics 20(1):1-18.

Ayoob, Mohammed. 2007. The many faces of political Islam. Ann Arbor, MI: University of Michigan Press.

Bayat, Asaf. 2007. Making Islam democratic: Social movements and the post-Islamist turn. Stanford: Stanford University Press.

Bratton, Michael. 2003. Briefing: Islam, democracy and public opinion in Africa. African Affairs 102(408):493-501.

Brown, Nathan J. 1997. Shari’a and State in the Modern Muslim Middle East. International Journal of Middle East Studies 29(3):359-376.

Brown, Nathan, J., Amr Hamzawy, and Marina Ottaway. 2006. Islamist movements and the democratic process in the Arab World: exploring gray zones. Carnegie Endowment Carnegie Paper 67.

Ciftci, Sabri. 2010. Modernization, Islam, or social capital: What explains attitudes toward democracy in the Muslim World. Comparative Political Studies 43(11):14421470.

Davis, Nancy J. and Robert V. Robinson. 2006. The egalitarian face of Islamic orthodoxy: Support for Islamic law and economic justice in seven Muslim-majority nations. American Sociological Review 71(2):167-190.

El-Affendi, Abdelwahab. 2003. The elusive reformation. Journal of Democracy 14(2):34-39. 
El-Fadl, Khaled Abou, Joshua Cohen, \& Deborah Chasman. 2004. Islam and the challenge of democracy. Princeton: Princeton University Press.

Esposito, John L, \& Dalia Mogahed. 2007. Who speaks for Islam? What a billion Muslims really think. New York, NY: Gallup Press.

Feldman, Noah. 2008. The fall and rise of the Islamic state. Princeton, NJ: Princeton University Press.

Feldman, S. 2003. Values, ideology, and the structure of political attitudes. In Oxford handbook of political psychology, eds. David O. Sears, Leonie Huddy, \& Robert Jervis. New York, NY: Oxford University Press.

Filali-Ansary, Abdou. 2003. The sources of enlightened Muslim thought. Journal of Democracy 14(2):19-33.

Fish, M. Steven. 2002. Islam and authoritarianism. World Politics. 55(1): 4-37.

Gellner, Ernest. 1981. Muslim society. Cambridge, UK: Cambridge University Press. Hassan, Riaz. 2008. Inside Muslim minds: Understanding contemporary Islamic consciousness. Melbourne, Australia: Melbourne University Press.

Hefner, Robert W. 2011. Shari'a politics: Islamic law and society in the modern world. Bloomington, IN: Indiana University Press.

Henry, Clement, M. 1990. Islamic banks and competitive politics in the Arab World and Turkey. Middle East Journal 44(2):234-255.

Hoffman, Steven. 2004. Islam and democracy: Micro-level indications of compatibility. Comparative Political Studies 37:652-676.

Hunter, Shireen. 1995. The rise of Islamist movements and the Western response: Clash of civilizations or clash of interests? In The Islamist dilemma: The political role of 
Islamist movements in the contemporary Arab World, ed. Laura Guazzone. London: Ithaca Press.

Hunter, Shireen. 1998. The future of Islam and the West: Clash of civilizations or peaceful coexistence. Westport, CT: Praeger.

Huntington, Samuel P. 1996. The clash of civilizations and the remaking of world order. New York: Simon \& Schuster.

Ibrahim, Saad Eddin. 1980. Anatomy of Egypt's militant Islamic groups: Methodological note and preliminary findings. International Journal of Middle East Studies 12:423-53. Inglehart, Ronald, \& Pippa Norris. 2003. The true clash of civilizations. Foreign Policy 135:62-70.

Inglehart, Ronald; and Christian Welzel. 2005. Modernization, cultural change, and democracy: the human development sequence. New York, NY: Cambridge University Press.

Jamal, Amaney, \& Mark A. Tessler. 2008. Attitudes in the Arab World. Journal of Democracy 19(1):97-110.

Jamal, Amaney. 2006. Reassessing support for Islam and democracy in the Arab World? Evidence from Egypt and Jordan. World Affairs 169(2):51-63.

Jamal, Amaney. 2007a. Barriers to democracy: The other side of social capital in Palestine and the Arab World. Princeton, NJ: Princeton University Press. Jamal, Amaney. 2007b. When is social trust a desirable outcome? Comparative Political Studies 40:1328-1349.

Karpat, Kemal H. 2001. The politicization of Islam Reconstructing identity, state, faith, and community in the late Ottoman state. New York, NY: Oxford University Press. 
Kedourie, Elie. 1992. Democracy and Arab political culture. Washington, D.C.:

Washington Institute for Near East Policy.

Lewis, Bernard. 2002. What went wrong? : Western impact and Middle Eastern

response. Oxford, NY: Oxford University Press.

Mernissi, Fatima. 1996. Women's rebellion \& Islamic memory. Atlantic Highlands, NJ:

Zed Books.

Moaddel, Mansoor. 2007. Values and perceptions of the Islamic and Middle Eastern

publics. New York: Palgrave Macmillan.

Nasr, Seyyed Vali Reza. 2005. The rise of "Muslim democracy.” Journal of Democracy 16(2):13-27.

Owen, Roger. 2004. State, power and politics in the making of the modern Middle East, New York, NY: Routledge.

Putnam, Robert D. 1993. Making democracy work: Civic traditions in modern Italy.

Princeton, NJ: Princeton University Press.

Ramadan, Tariq. 2009. Radical reform: Islamic ethics and liberation. Oxford: Oxford Univ. Press.

Roy, Olivier. 1994. The failure of political Islam. Cambridge, MA: Harvard University Press.

Sachedina, Abdulaziz Abdulhussein. 2001. The Islamic roots of democratic pluralism. New York: Oxford University Press.

Schwartz, SE. 1992. Universals in the content and structure of values: Theoretical advances and empirical tests in 20 countries. Advances in Experimental Social Psychology 25(1): 1-65. 
Singerman, Diane. 1996. Avenues of participation : family, politics, and networks in urban quarters of Cairo. Princeton, NJ: Princeton University Press.

Tessler, Mark. 2002. Islam and democracy in the Middle East: The impact of religious orientations on attitudes toward democracy in four Arab countries. Comparative Politics 34(2):33-54.

Tessler, Mark. 2011. Popular views about Islam and Politics in the Arab World. Last accessed June 2011. http://www.lsa.umich.edu/UMICH/ii/Home/II\%20Journal /Documents/2011fall_iijournal_article1.pdf

The Algerian Constitution. 1976. Last accessed September 2011. http://www.conseilconstitutionnel.dz/indexFR.htm

The Moroccon Constitution. 1996. Last accessed on September 2011. http://confinder.richmond.edu/admin/docs/Morocco.PDF Wright, Robin B. 1996. Islam and liberal democracy: Two visions of reformation. Journal of Democracy 7(2):65-7.

Zubaida, Sami. 1993. Islam, the people and the state: political ideas and movements in the Middle East. London: I.B. Tauris. 
Figure 1: Support for Democracy and Support for Shari'a in the Arab World*

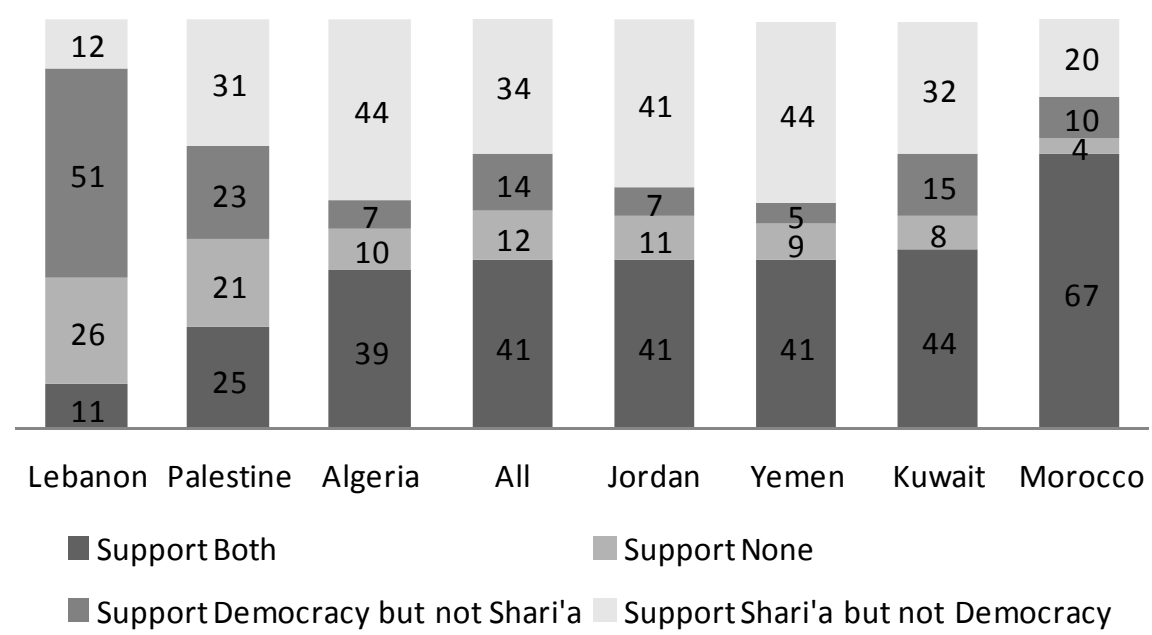

*The figures represent the percentage of respondents falling under each category. Data is obtained from the First Wave of the Arab Barometer Surveys. 
Table 1: Bivariate Probit Analysis of Support for Shari'a and Support for Democracy in the Arab World: *

\begin{tabular}{|c|c|c|c|c|}
\hline \multirow[b]{2}{*}{ VARIABLES } & \multicolumn{2}{|c|}{ Model 1} & \multicolumn{2}{|c|}{ Model 2} \\
\hline & Democracy & Shari’a & Democracy & Shari’a \\
\hline \multirow[t]{2}{*}{ Political Trust } & $0.098 * * *$ & $0.053 * *$ & $0.072 * * *$ & 0.020 \\
\hline & $(0.029)$ & $(0.026)$ & $(0.019)$ & $(0.021)$ \\
\hline \multirow[t]{2}{*}{ Interpersonal Trust } & -0.073 & -0.050 & 0.052 & -0.070 \\
\hline & $(0.064)$ & $(0.060)$ & $(0.042)$ & $(0.048)$ \\
\hline \multirow[t]{2}{*}{ Gender Attitudes } & $0.204 * * *$ & $-0.058 *$ & $0.130 * * *$ & $-0.058 * *$ \\
\hline & $(0.036)$ & $(0.033)$ & $(0.023)$ & $(0.027)$ \\
\hline \multirow[t]{2}{*}{ Anti-West } & $0.108^{*}$ & $0.103^{*}$ & 0.025 & 0.077 \\
\hline & $(0.064)$ & $(0.060)$ & $(0.041)$ & $(0.048)$ \\
\hline \multirow[t]{2}{*}{ Non-Secular } & -0.033 & $0.266 * * *$ & $-0.057 * * *$ & $0.264 * * *$ \\
\hline & $(0.024)$ & $(0.022)$ & $(0.015)$ & $(0.018)$ \\
\hline \multirow[t]{2}{*}{ Islamic View (Economics) } & $0.060 * *$ & $0.131 * * *$ & $0.031 *$ & $0.135 * * *$ \\
\hline & $(0.027)$ & $(0.024)$ & $(0.017)$ & $(0.019)$ \\
\hline \multirow[t]{2}{*}{ Islamic View (Legal System) } & $-0.071^{* * *}$ & $0.053 * * *$ & $-0.048 * * *$ & $0.047 * * *$ \\
\hline & $(0.023)$ & $(0.020)$ & $(0.014)$ & $(0.016)$ \\
\hline \multirow[t]{2}{*}{ Age } & -0.036 & -0.021 & 0.009 & -0.021 \\
\hline & $(0.022)$ & $(0.020)$ & $(0.014)$ & $(0.016)$ \\
\hline \multirow[t]{2}{*}{ Female } & $-0.348 * * *$ & 0.061 & $-0.253 * * *$ & 0.060 \\
\hline & $(0.061)$ & $(0.056)$ & $(0.039)$ & $(0.045)$ \\
\hline \multirow[t]{2}{*}{ Education } & $0.124 * * *$ & $0.071 * * *$ & $0.079 * * *$ & $0.048 * * *$ \\
\hline & $(0.021)$ & $(0.020)$ & $(0.014)$ & $(0.016)$ \\
\hline \multirow[t]{2}{*}{ Religious } & 0.037 & $0.087 * * *$ & -0.008 & $0.085 * * *$ \\
\hline & $(0.024)$ & $(0.023)$ & $(0.016)$ & $(0.018)$ \\
\hline \multirow[t]{2}{*}{ Income } & $0.053 * * *$ & 0.007 & $0.012^{*}$ & 0.008 \\
\hline & $(0.011)$ & $(0.010)$ & $(0.007)$ & $(0.008)$ \\
\hline \multirow[t]{2}{*}{ Jordan } & $-0.846 * * *$ & $-0.354 * * *$ & $-0.902 * * *$ & $-0.252 * * *$ \\
\hline & $(0.103)$ & $(0.097)$ & $(0.068)$ & $(0.081)$ \\
\hline \multirow[t]{2}{*}{ Palestine } & $-0.459 * * *$ & $-1.317 * * *$ & $-0.877 * * *$ & $-1.193 * * *$ \\
\hline & $(0.109)$ & $(0.094)$ & $(0.066)$ & $(0.075)$ \\
\hline \multirow[t]{2}{*}{ Algeria } & $-1.113^{* * *}$ & -0.179 & $-0.962 * * *$ & $-0.171^{*}$ \\
\hline & $(0.112)$ & $(0.111)$ & $(0.074)$ & $(0.090)$ \\
\hline \multirow[t]{2}{*}{ Kuwait } & -0.177 & -0.017 & $-0.678 * * *$ & -0.104 \\
\hline & $(0.158)$ & $(0.129)$ & $(0.087)$ & $(0.101)$ \\
\hline \multirow[t]{2}{*}{ Lebanon } & $-0.585^{* * *}$ & $-1.668 * * *$ & $-0.751 * * *$ & $-1.587 * * *$ \\
\hline & $(0.156)$ & $(0.129)$ & $(0.095)$ & $(0.107)$ \\
\hline \multirow[t]{2}{*}{ Yemen } & $-0.945^{* * *}$ & $-0.275^{* *}$ & $-0.760 * * *$ & -0.077 \\
\hline & $(0.118)$ & $(0.113)$ & $(0.079)$ & $(0.096)$ \\
\hline \multirow[t]{2}{*}{ Constant } & 0.253 & $-0.828 * * *$ & 0.183 & $-0.658 * * *$ \\
\hline & $(0.240)$ & $(0.217)$ & $(0.156)$ & $(0.178)$ \\
\hline Observations & 3,252 & 3,252 & 5,021 & 5,021 \\
\hline LR Test of Rho & $33.45^{* * *}$ & $\mathrm{p}<$ Chi2 $=0.000$ & \multirow{2}{*}{\multicolumn{2}{|c|}{$3.20 * \quad \mathrm{p}<$ Chi2 $=0.07$}} \\
\hline Standard errors in parentheses, & $* * * \mathrm{p}<0.01, * *$ & $05, * \mathrm{p}<0.1$ & & \\
\hline
\end{tabular}


Figure 2: Marginal Impact of covariates on Conditional and Independent Support for Shari'a and Democracy*

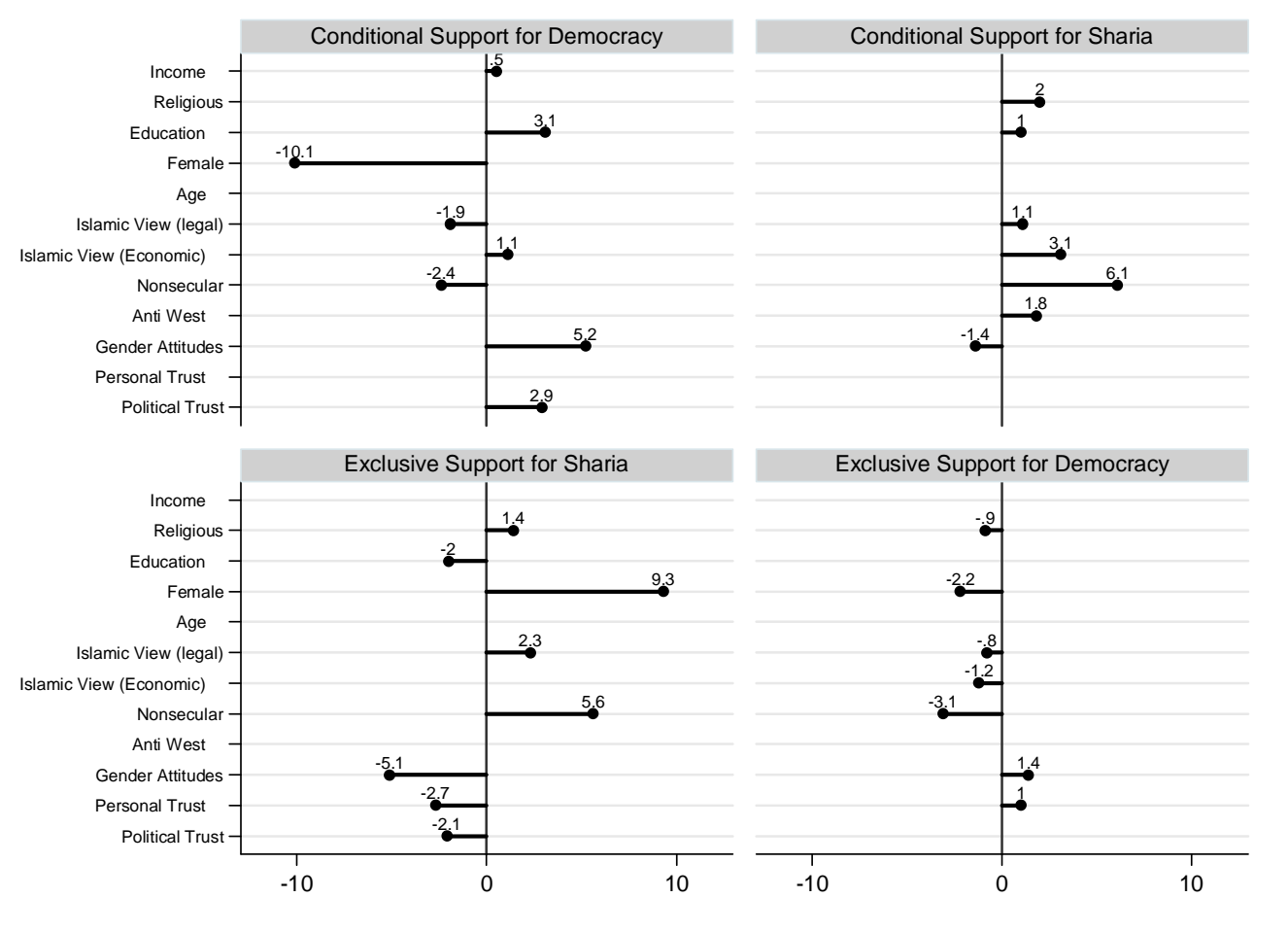

*The upper panel shows marginal effects on support for democracy equation given support for shari'a or the other way around. The lower panel shows support for democracy when no support exists for shari'a and vice versa. 
Table 2: Probit Estimation of Support for Shari'a and Democracy in Seven Arab Polities

\begin{tabular}{|c|c|c|c|c|c|c|c|c|c|c|c|c|c|c|}
\hline & \multicolumn{2}{|c|}{ JORDAN } & \multicolumn{2}{|c|}{ PALESTINE } & \multicolumn{2}{|c|}{ ALGERIA } & \multicolumn{2}{|c|}{ MOROCCO } & \multicolumn{2}{|c|}{ KUWAIT } & \multicolumn{2}{|c|}{ LEBANON } & \multicolumn{2}{|c|}{ YEMEN } \\
\hline & DEMOC. & SHARIA & DEMOC. & SHARIA & DEMOC. & SHARIA & DEMOC. & SHARIA & DEMOC. & SHARIA & DEMOC. & SHARIA & DEMOC. & SHARIA \\
\hline \multirow[t]{2}{*}{ Political Trust } & 0.047 & 0.004 & $0.089 * *$ & 0.041 & 0.061 & -0.046 & $-0.067 *$ & $0.137 * * *$ & $0.550 * * *$ & 0.060 & 0.098 & -0.092 & 0.088 & $-0.195 * * *$ \\
\hline & $(0.044)$ & $(0.053)$ & $(0.040)$ & $(0.041)$ & $(0.051)$ & $(0.065)$ & $(0.039)$ & (0.049) & $(0.100)$ & $(0.101)$ & $(0.082)$ & $(0.097)$ & $(0.059)$ & $(0.073)$ \\
\hline \multirow{2}{*}{$\begin{array}{l}\text { Interpersonal } \\
\text { Trust }\end{array}$} & $0.162 *$ & -0.121 & -0.035 & $-0.170 * *$ & -0.182 & 0.142 & 0.019 & -0.078 & -0.054 & $0.813^{* * *}$ & 0.108 & 0.034 & $0.221^{*}$ & 0.087 \\
\hline & $(0.085)$ & $(0.102)$ & $(0.080)$ & $(0.083)$ & $(0.151)$ & $(0.200)$ & $(0.109)$ & $(0.128)$ & $(0.202)$ & $(0.253)$ & $(0.213)$ & $(0.253)$ & $(0.122)$ & $(0.157)$ \\
\hline \multirow{2}{*}{$\begin{array}{l}\text { Gender } \\
\text { Attitudes }\end{array}$} & $0.112^{* *}$ & -0.074 & $0.116^{* *}$ & -0.074 & $0.276^{* * *}$ & 0.055 & $0.119 * *$ & 0.025 & 0.129 & -0.055 & 0.058 & $-0.297 * *$ & 0.038 & -0.093 \\
\hline & $(0.054)$ & $(0.066)$ & $(0.055)$ & $(0.057)$ & $(0.066)$ & $(0.086)$ & $(0.047)$ & $(0.057)$ & $(0.101)$ & $(0.117)$ & (0.099) & (0.118) & $(0.069)$ & $(0.086)$ \\
\hline \multirow[t]{2}{*}{ Anti West } & 0.121 & -0.006 & -0.081 & $0.229 * * *$ & 0.100 & 0.029 & $-0.207 * *$ & 0.028 & 0.057 & -0.433 & 0.196 & 0.001 & $0.231^{*}$ & -0.100 \\
\hline & $(0.082)$ & $(0.100)$ & $(0.081)$ & $(0.085)$ & $(0.123)$ & $(0.160)$ & $(0.093)$ & $(0.117)$ & $(0.302)$ & $(0.328)$ & $(0.191)$ & $(0.217)$ & $(0.135)$ & $(0.174)$ \\
\hline \multirow[t]{2}{*}{ Non-secular } & $-0.104 * * *$ & $0.215^{* * *}$ & $-0.065^{* *}$ & $0.306^{* * *}$ & $-0.071^{*}$ & $0.345^{* * *}$ & 0.042 & $0.326 * * *$ & 0.057 & 0.084 & -0.040 & $0.289 * * *$ & $-0.134 * * *$ & 0.070 \\
\hline & $(0.034)$ & $(0.043)$ & $(0.031)$ & $(0.033)$ & $(0.041)$ & $(0.058)$ & $(0.035)$ & $(0.039)$ & $(0.065)$ & $(0.079)$ & $(0.070)$ & $(0.078)$ & $(0.050)$ & $(0.068)$ \\
\hline \multirow{2}{*}{$\begin{array}{l}\text { Islamic View } \\
\text { (Economic) }\end{array}$} & $0.097^{* *}$ & $0.208^{* * *}$ & -0.015 & 0.047 & -0.024 & $0.233^{* * *}$ & $0.068 *$ & $0.104^{* *}$ & 0.038 & $0.273^{* * *}$ & 0.064 & 0.087 & -0.031 & $0.116^{*}$ \\
\hline & $(0.038)$ & $(0.043)$ & $(0.037)$ & $(0.038)$ & $(0.053)$ & $(0.060)$ & $(0.038)$ & $(0.044)$ & $(0.068)$ & $(0.077)$ & $(0.064)$ & (0.079) & $(0.052)$ & $(0.063)$ \\
\hline \multirow{2}{*}{$\begin{array}{l}\text { Islamic View } \\
\text { (legal) }\end{array}$} & -0.044 & 0.021 & 0.017 & $0.096^{* * *}$ & 0.033 & $0.092^{*}$ & $-0.111^{* * *}$ & 0.041 & $-0.139 * *$ & 0.081 & -0.060 & $0.128 *$ & $-0.133^{* * *}$ & -0.026 \\
\hline & $(0.032)$ & (0.039) & $(0.031)$ & $(0.032)$ & $(0.042)$ & $(0.055)$ & $(0.030)$ & $(0.035)$ & $(0.057)$ & (0.069) & $(0.070)$ & $(0.075)$ & $(0.044)$ & $(0.055)$ \\
\hline \multirow[t]{2}{*}{ Age } & $-0.076^{* *}$ & -0.009 & 0.020 & 0.009 & -0.009 & -0.047 & -0.005 & 0.018 & 0.049 & 0.094 & 0.066 & $-0.136^{*}$ & 0.091 & $-0.369 * * *$ \\
\hline & $(0.031)$ & $(0.037)$ & $(0.030)$ & $(0.031)$ & $(0.044)$ & $(0.054)$ & $(0.032)$ & $(0.038)$ & $(0.054)$ & $(0.066)$ & $(0.065)$ & $(0.077)$ & $(0.061)$ & $(0.078)$ \\
\hline \multirow[t]{2}{*}{ Female } & $-0.345^{* * *}$ & $0.228^{* *}$ & -0.132 & -0.105 & $-0.329 * * *$ & 0.134 & $-0.277 * * *$ & 0.017 & -0.224 & $0.730^{* * *}$ & $-0.415^{* *}$ & 0.050 & -0.092 & $-0.324 * *$ \\
\hline & $(0.085)$ & $(0.105)$ & $(0.082)$ & $(0.085)$ & $(0.115)$ & $(0.147)$ & $(0.090)$ & $(0.106)$ & $(0.167)$ & $(0.181)$ & $(0.196)$ & $(0.234)$ & $(0.122)$ & $(0.158)$ \\
\hline \multirow[t]{2}{*}{ Education } & 0.031 & $0.122 * * *$ & $0.104 * * *$ & -0.046 & $0.118 * * *$ & $0.127^{* * *}$ & -0.044 & $0.102^{* *}$ & 0.050 & 0.092 & $0.154 * * *$ & $-0.143 * *$ & $0.285^{* * *}$ & 0.053 \\
\hline & $(0.033)$ & $(0.041)$ & $(0.032)$ & $(0.034)$ & $(0.036)$ & $(0.045)$ & $(0.030)$ & $(0.042)$ & $(0.057)$ & $(0.070)$ & (0.059) & $(0.069)$ & $(0.043)$ & $(0.051)$ \\
\hline \multirow[t]{2}{*}{ Religious } & 0.001 & $0.113 * * *$ & -0.001 & 0.023 & 0.013 & $0.098^{*}$ & 0.033 & 0.019 & -0.089 & $0.209 * *$ & 0.005 & $0.223^{* * *}$ & 0.042 & $0.172^{* * *}$ \\
\hline & $(0.034)$ & $(0.040)$ & $(0.036)$ & $(0.038)$ & $(0.047)$ & $(0.059)$ & $(0.033)$ & $(0.040)$ & $(0.087)$ & $(0.104)$ & $(0.064)$ & $(0.078)$ & $(0.056)$ & $(0.067)$ \\
\hline \multirow[t]{2}{*}{ Income } & 0.018 & 0.016 & -0.023 & -0.001 & $0.046^{* *}$ & 0.001 & $0.049 * * *$ & 0.015 & -0.033 & 0.044 & 0.039 & -0.009 & $-0.038^{*}$ & 0.029 \\
\hline & $(0.015)$ & $(0.019)$ & $(0.015)$ & $(0.016)$ & $(0.018)$ & $(0.024)$ & $(0.016)$ & $(0.019)$ & $(0.028)$ & $(0.032)$ & $(0.031)$ & $(0.038)$ & $(0.021)$ & $(0.027)$ \\
\hline \multirow[t]{2}{*}{ Constant } & -0.406 & $-1.334 * * *$ & $-0.682 * *$ & $-1.215^{* * *}$ & $-1.547 * * *$ & $-2.124 * * *$ & 0.379 & $-1.374 * * *$ & $-1.464 * *$ & $-2.574 * * *$ & $-1.147^{*}$ & -0.495 & $-0.806 *$ & $1.372^{* *}$ \\
\hline & $(0.348)$ & $(0.415)$ & $(0.331)$ & $(0.345)$ & $(0.510)$ & $(0.645)$ & $(0.335)$ & (0.387) & $(0.733)$ & (0.898) & $(0.597)$ & $(0.687)$ & $(0.478)$ & $(0.600)$ \\
\hline Observations & 1039 & 1034 & 1068 & 1068 & 627 & 619 & 1118 & 1113 & 326 & 326 & 299 & 299 & 567 & 567 \\
\hline
\end{tabular}

*Standard errors in parentheses, $\quad * * * \mathrm{p}<0.01, * * \mathrm{p}<0.05, * \mathrm{p}<0.1$

* Statistically significant variables are shaded. 